Arq. Bras. Med. Vet. Zootec., v.69, n.6, p.1419-1425, 2017

\title{
Implementation of immobilization accessories for positioning of small animals for radiation therapy
}

\author{
[Implementação de acessórios de imobilização para o posicionamento de \\ pequenos animais para a radioterapia] \\ M.C. Vettorato ${ }^{1}$, C.H. Girotto ${ }^{1}$, J.L. Fogaça ${ }^{1}$, L.C. Vulcano ${ }^{1}$, M.A.R. Fernandes ${ }^{2}$ \\ ${ }^{1}$ Universidade Estadual Paulista "Júlio de Mesquita Filho" - Faculdade de Medicina \\ Veterinária e Zootecnia, Botucatu, SP \\ ${ }^{2}$ Universidade Estadual Paulista "Júlio de Mesquita Filho" - Faculdade de Medicina de Botucatu, SP
}

\begin{abstract}
Radiation therapy is a modality that is presenting great advances in veterinary medicine worldwide. In Brazil, this therapeutic option is underachieved. The success of this method depends on several factors, including the use of appropriate accessories for protection and immobilization of patients. For the immobilization of small animals during treatment, in addition to sedation and anesthesia, immobilizing accessories, similar to those used in human radiotherapy, are used. This study aimed to present proposals for immobilizing accessories adapted to the positioning of small animals in order to be used in radiotherapy planning. In order to achieve results, accessories were made and tested in a living animal simulating a radiotherapy planning, which proved to be favorable to use in positioning small animals undergoing radiotherapy and for implementation processes.
\end{abstract}

Keywords: veterinary radiotherapy, immobilizing accessories, small animals

\section{RESUMO}

A radioterapia é uma modalidade que tem apresentando grandes avanços dentro da medicina veterinária pelo mundo. No Brasil, essa opção terapêutica é pouco realizada. O sucesso dessa modalidade depende de vários fatores, entre eles, o uso de acessórios adequados para a proteção e imobilização dos pacientes. Para a imobilização dos pequenos animais durante o tratamento, além da sedação e da anestesia, são utilizados acessórios imobilizadores semelhantes aos usados na radioterapia humana. Devido a isso, este trabalho teve como objetivo de apresentar propostas de acessórios de imobilização adaptados ao posicionamento de pequenos animais para o uso nos planejamentos radioterápicos. Para a sua realização, foram confeccionados acessórios e testados em um animal vivo simulando um planejamento radioterápico, os quais mostraram ser favoráveis ao uso nos posicionamento de pequenos animais submetidos à radioterapia e para sua implementação.

Palavras-chave: radioterapia veterinária, acessórios de imobilização, pequenos animais

\section{INTRODUCTION}

Radiation therapy is a well established medical modality for the treatment of cancer (Andrade and Fernandes, 2015; Felix et al., 2015). In the area of veterinary medicine, radiotherapy has been presented as an important therapeutic option in the routine of small animals (Nelson and Couto, 2015) and has been continuously growing (Mcentee, 2004; Vettorato et al., 2017). However, in Brazil, the application of veterinary

Recebido em 9 de novembro de 2016

Aceito em 11 de fevereiro de 2017

E-mail: m_vettorato@hotmail.com radiotherapy is scarcely carried out, limited to research in few veterinary hospitals established in some universities in the country, such as the Fluminense Federal University (UFF) and the School of Veterinary Medicine of Araçatuba (FMVA/UNESP) (Cunha et al., 2007; Fernandes et al., 2010; Cunha et al., 2014).

Radiation therapy can be performed with the radiation source close to or in contact with the lesion (brachytherapy), or with the distant tumor source (teletherapy) (Burk and King, 1997; Moore, 2002). 


\section{Vettorato et al.}

Both techniques require careful planning to ensure the distribution of the radiation dose as recommended by the veterinarian radiotherapist (Morris and Dobson, 2007).

The radiotherapy protocols applied in veterinary medicine vary depending on various factors such as: availability of equipment and radioactive sources, economic, customer preferences, handling and animal logistics (Burk and King, 1997; Withrow et al., 2013). Clinical staging of the disease is also a preponderant factor in choosing the treatment plan (Schwarz and Saunders, 2011).

The conscious application of radiotherapy requires a multiprofessional team, consisting mainly of: veterinarian radiotherapist, medical physicist and radiology technologist (Boston and Henderson, 2014). Before the start of radiotherapy, the treatment simulation is performed. The objective of this study is to determine the patient's positioning, to identify target volumes and organs at risk, to determine and verify the geometry of the treatment fields, and to generate digitally reconstructed radiographs for comparison with the portal images (Gonçalves, 2013).

This methodology, when used, for example, in the simulation of prostate cancer in humans by computerized tomography, three gold fiducial markers are inserted into the prostate within three to four weeks before treatment to ensure isocenter of the patient's lesions in images acquired subsequent to radiotherapy planning (Chen et al., 2007). The use of fiducial markers in the simulation has also collaborated with the radiotherapy planning through tomography in patients with lung cancer (Macmanus et al., 2007) and primary liver cancer (Abe et al., 2016).

The success of radiotherapy depends on several factors, including the use of appropriate accessories for the protection and immobilization of patients. These devices must have characteristics that contribute to the comfortable handling of the patient and allow the focusing of the radiation field restricted to the volume of treatment and do not interfere in the released radiation dose (Lage et al., 2012; Maruo et al., 2013).
Most radiotherapy procedures in veterinary medicine require the sedation or even the anesthesia of the animal. This fact requires the use of locking accessories specifically designed for the different species of animals and treated according to the respective procedures shown (Andrade and Fernandes, 2015; Hansen et al., 2015).

For the immobilization of small animals during treatment, as well as sedation and anesthesia are used some accessories like immobilizers to those used in human radiotherapy such as frames or frames for head thermoplastic masks, bite blocks and moldable mattresses (Kippenes et al., 2000; Green et al., 2003; Schwarz and Saunders, 2011; Maruo et al., 2013; Larue and Custis, 2014; Hansen et al., 2015).

Due to this, the objective of this work was to present proposals of immobilization accessories adapted to the positioning of small animals for use in the radiotherapy plans.

\section{MATERIALS AND METHODS}

For the accomplishment of this methodology, the research was approved by the Ethics Committee on the Use of Animals (CEUA) of the School of Veterinary Medicine and Animal Science of Botucatu (FMVZ/UNESP) (Protocol n06/2016).

An accessory of the ramp type was made for immobilization and positioning of the veterinary patient submitted to radiotherapy. The ramp is made of wood type Medium Density Fiberboard (MDF), divided into 4 parts, with two $60.0 \mathrm{~cm}$ wide and $50.0 \mathrm{~cm}$ long and two with $60.0 \mathrm{~cm}$ wide and $45.0 \mathrm{~cm}$ length, with a total length of $1.90 \mathrm{~m}$. The thickness of the MDF plates was $1.5 \mathrm{~cm}$. For the better preparation of the animal and radiation dose planning, acrylic wedges were made, which were fixed in predetermined holes in the plane of the ramp.

To make the wedges, a smooth acrylic plate with $1 \mathrm{~cm}$ thickness, $100 \mathrm{~cm}$ width and $200 \mathrm{~cm}$ length was used. Pairs of wedges with different measurements, $5 \mathrm{~cm}$ wide by $35 \mathrm{~cm}$ long, $10 \mathrm{~cm}$ wide by $35 \mathrm{~cm}$ long, and $15 \mathrm{~cm}$ wide by $35 \mathrm{~cm}$ long, were formed.

Two more accessories were also created, a tooth holder with height adjusters and a base holder for 
fixing the thermoplastic mask. The support for the thermoplastic mask was adapted with measures similar to those used in human radiotherapy services.

A pilot study was conducted by testing the accessories produced in a non-breed bitch (SRD) from the FMVZ / UNESP kennel, aged 3 years and approximately $19 \mathrm{~kg}$ after the 8 -hour fast. For the simulation, the radiotherapy planning was based on the main protocols (Theon and Feldman, 1998; Kent et al., 2007; Fornel et al., 2007; Moore and O'Brien, 2008; Michelon et al., 2012; Nelson and Couto, 2015; Marcinowska et al., 2015; Bley et al.,2016), which was selected a case of a dog with pituitary macrotumor for the exclusive use of the accessory produced.

A pre-anesthetic medication based on acepromazine $(0.03 \mathrm{mg} / \mathrm{kg})$ and morphine $(0.5 \mathrm{mg} / \mathrm{kg})$ administered intramuscularly was used to sedate the animal. Anesthetic induction was performed intravenously with propofol $(4 \mathrm{mg} / \mathrm{kg})$ and the anesthetic maintenance was with isoflurane.

The dental mold was made with condensation silicone, made of hydrophilic impression material (Speedex putty, Coltene () for dental use combined with a $60 \mathrm{ml}$ Universal Speedex Catalyst, with a set time of 5 to 10 minutes.

The animal was positioned on the immobilizer on the wedges in the ventral decubitus position with the thoracic limbs extended rostrally and the pelvic caudally. The thermoplastic material mask was heated in water to $70^{\circ} \mathrm{C}$ and, after being softened, was placed on the patient's head and onto the dental support until it cooled and hardened. A hole was made in the mask for the passage of the endotracheal tube of inhalation anesthesia during the cooling of the material.

Some foam pads were used in the lateral region of the abdomen and another as a base for the head, providing more comfort for the animal. After fixation of the dental mold and the thermoplastic mascara, the fiducial markers were introduced under the hardened mask delimiting the center and the margins of the treatment field and subsequently marked on adhesive tapes with a pen.
A tomography of the skull with parallel axial cuts was performed in the immobilized animal, aiming to identify the fiducial markers. For this, we used a Shimadzu scanner (Model 7800 TCS Helical CT of channel 1), $2 \mathrm{~mm}$ thick and increment, $120 \mathrm{kV}$ and $150 \mathrm{~mA}$ 2. Pitch and a reconstruction was performed in the sagittal and dorsal, through multiplanar reformatting (MPR) and reconstruction of the $3 \mathrm{D}$ image.

\section{RESULTS AND DISCUSSIONS}

The conditioning ramp associated with the acrylic wedges (Figure 1) provided excellent immobilization of the animal favoring a better homogeneity of the radiation dose distribution throughout the treatment field. In this case of the study, an immobilization mask was also made for the head and neck region, which facilitated the positioning in the animal and placement of the fiducial markers before the tomography (Figure 2).

All the steps of the simulation, from the arrival of the animal in the tomography room until its recovery from the anesthesia, summed to a total time of 1 hour and 20 minutes, which highlights the practicality in the application of the accessory produced.

The use of the positioning ramp made in the present study, provided greater agility in anesthesia procedures, optimizing the activities of the professionals. The compact and modular form of the positioning ramp and the packing wedges also allow the use of the accessory for animals of different dimensions.

The accessories shown in the present study all features disclosed by Lage et al. (2012), and the similarity to other immobilizers accessories used in small animals in the literature (Kippenes et al., 2000; Green et al., 2003; Schwarz and Saunders, 2011; Maruo et al., 2013; Larue and Custis, 2014; Hansen et al., 2015).

The dimensions of the fittings did not interfere with the tomographic examination, both in the physical part and in the tomographic image (Figure 3), which facilitates the radiotherapeutic planning, be it in three-dimensional conformational radiotherapy (3D-RCT), radiotherapy with intensity modulated (IMRT), or by another similar technique. 


\section{Vettorato et al.}

The procedures performed on animals followed the same methodology used by Michelon et al. (2012) in human skull simulations. According to these authors, the fiducial markers relate the patient's images, acquired during the simulation, planning and positioning thereof at the time of treatment. These markers ensure the reliability of patient placement during the examination, as they can be viewed in the images. In addition, the projection of the markers defines the isocenter of the lesion, usually located near the center of the target volume or at a specific point, being the reference for insertion of the treatment fields during the planning.

Because it was a healthy animal, it was not possible to assimilate the isocenter of the lesion with the fiducial markers. However, it was possible to visualize them in the tomography and to identify the symmetry between them, which can be significant for the radiotherapeutic planning, since it makes the patient more precise positioning in the treatment unit.

As reported by Michelon et al. (2012), during the acquisition of the images one can or not use radiographic contrast substances, which enhance or increase the density of blood vessels, soft tissues, organs and tumors. All this information is valuable in distinguishing between normal and pathological tissues. Thus, the application of contrast during the simulation may be an alternative to be used in radiotherapy procedures in small animals in veterinary medicine.

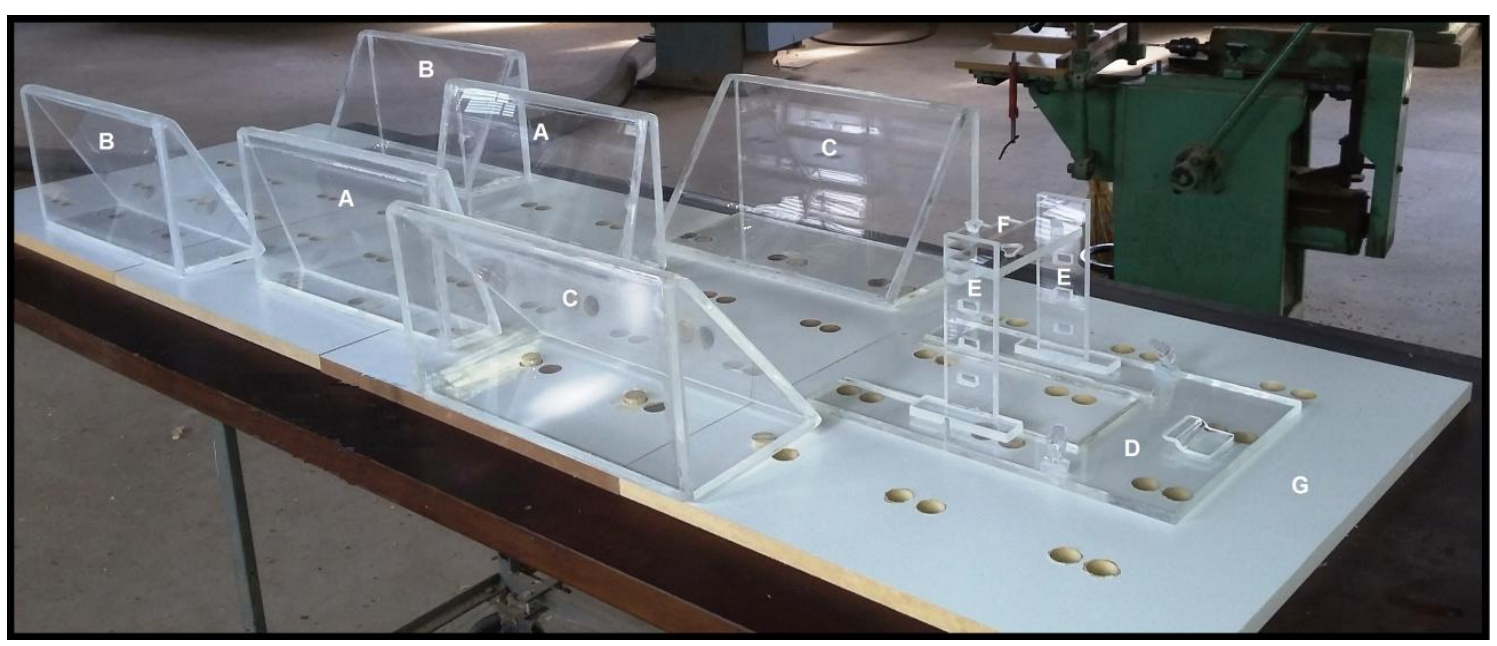

Figure 1. Immobilization accessories produced in the FMVZ and adapted for different anatomies of small animals (dogs and cats), the three pairs of acrylic wedges of $5^{\circ}(\mathrm{A}), 10^{\circ}(\mathrm{B})$ and $15^{\circ}(\mathrm{C})$, the base of (D), the right and left height adjuster (E) for the dental mold $(F)$ and the ramp with the 4 attached parts $(G)$.

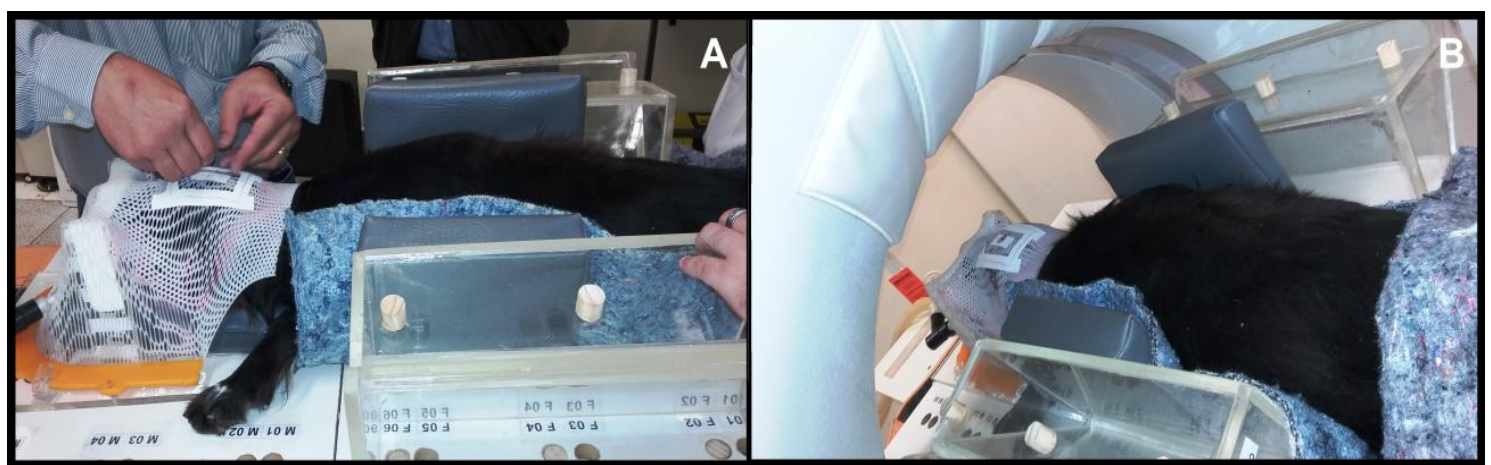

Figure 2. Fiducial markers being inserted in the thermoplastic mask of the animal (A) the positioning of the immobilized animal to the beginning of the tomography (B). 


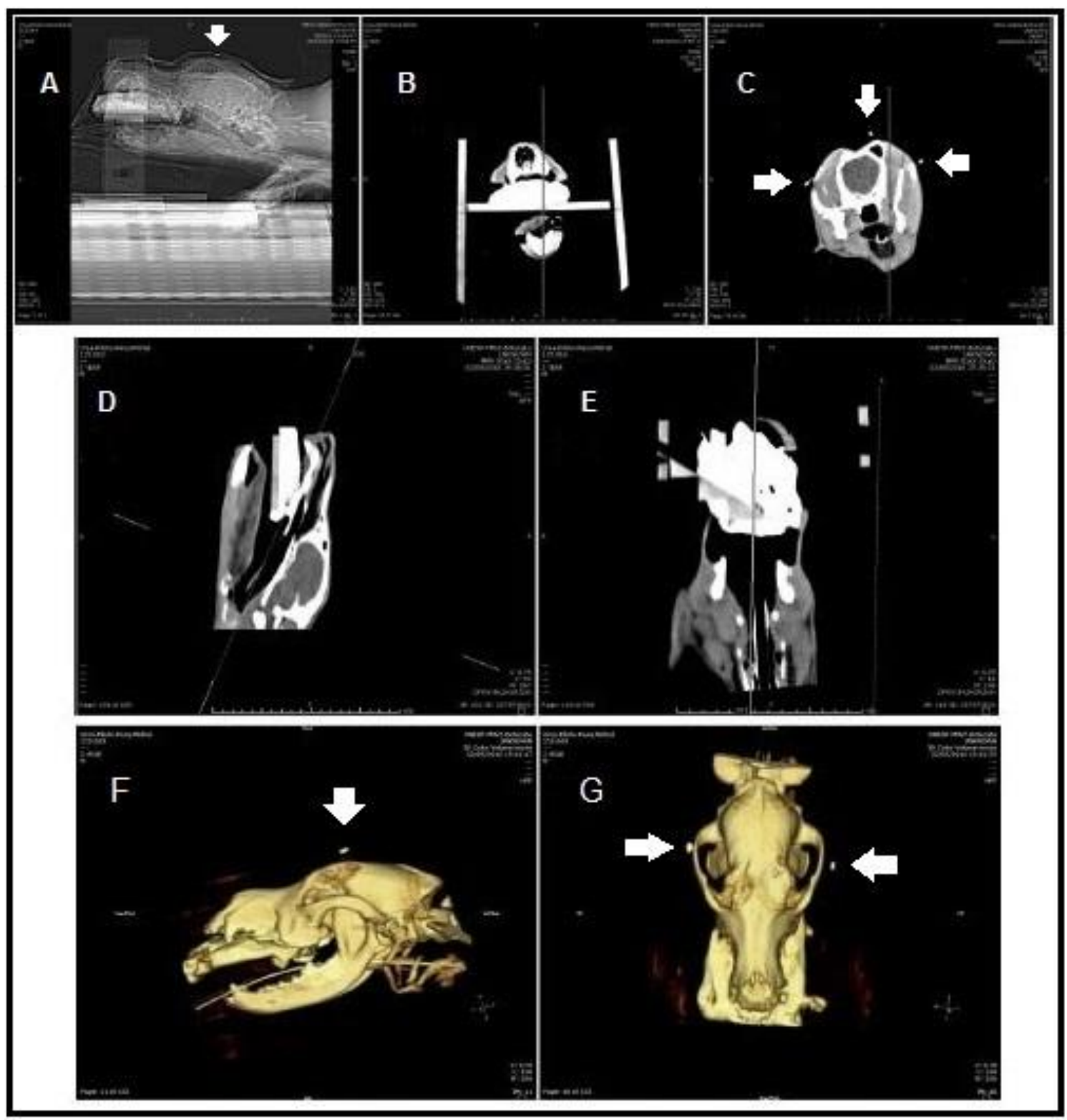

Figure 3. Computed tomography of the animal simulation (A to C), reconstruction in the sagittal and dorsal planes by MPR (D and E) and reconstruction of the 3D image (F and G). The fiducial markers are observed in the figures with white arrows.

During the experiment, the veterinary professionals who acted in the illustrated procedure approved the use of the accessories developed in the research and emphasized the practicality in the manipulation of the animal. Thus, its implementation in veterinary radiotherapy services may contribute to the applied radiotherapy plans.
However, in order to further improve the use of the accessories, future adaptations may be made and the improved material such as the production of more acrylic wedges the same or different measurements than those presented and the increase in the number of holes in each piece of the ramp. MDF, in this way, these adaptations would collaborate with their use in other species of animals. 


\section{Vettorato et al.}

\section{CONCLUSION}

The immobilization accessories produced in this study have shown to be viable for the use and positioning of small animals submitted to radiotherapy and for their implementation in a veterinary radiotherapy service.

\section{REFERENCES}

ABE, S.; KUBOTA, Y.; SHIBUYA, K. et al. Fiducial marker matching versus vertebral body matching: dosimetric impact of patient positioning in carbon ion radiotherapy for primary hepatic câncer. Phys. Med., p.1-7, 2016.

ANDRADE, A.L.; FERNANDES, M.R. Braquiterapia em medicina veterinária. In: JERICÓ, M.M.; ANDRADE NETO, J.P.; KOGIKA, M.M. Tratado de medicina interna de cães e gatos. São Paulo: Roca, 2015. v.2, p.560583.

BLEY, C.R. Letters to the editor: comparison of two coarse fractionated radiation protocols for the management of canine pituitary macrotumor: an observational study of 24 dogs, Marcinowska, Vet. Radiol. Ultrassound, v.57, p.107-109, 2016.

BOSTON, S.; HENDERSON, R.A. Role of surgery in múltimodal cancer therapy for small animals. Vet. Clin. N. Small Anim. Pract., v.44, p.855-870, 2014.

BURK, R.L.; KING, G.K. Radiation oncology. Philadelphia: W.B. Saunders Company, 1997. $171 \mathrm{p}$.

CHEN, J.; LEE, R.J.; HANDRAHAN, D.; SAUSE, W.T. Intensity modulated radiotherapy using implanted fiducial markers with daily portal imaging: assessment of prostate organ motion. Int. J. Radiat. Oncol. Biol. Phys., v.68, p.912-919, 2007.

CUNHA, S.C.S.; CARVALHO, L.A.V.; CANARY, P. et al. Aplicação da radioterapia em felino portador de carcinoma epidermóide nasal e palpebral utilizando protocolo de hipofracionamento. Acta Sci. Vet., v.35, p.239243, 2007.

CUNHA, S.C.S.; CARVALHO, L.A.V.; CORGOZINHO, K.B. et al. A utilização da radioterapia no tratamento do carcinoma de células escamosas cutâneo felino avançado. Arq. Bras. Med. Vet. Zootec., v.66, p.7-14, 2014.
FELIX, M.C.; FLECKENSTEIN, J.; KIRSCHNER, S. et al. Image-guided radiotherapy using a modified industrial microCT for preclinical applications. J. Plos One, v.10, p.1-11, 2015.

FERNANDES, M.A.R.; ANDRADE, A.L.; LUVIZOTO, M.C.R. et al. Radioterapia em Medicina veterinária princípios e perspectivas. Rev. Bras. Fís. Méd., v.4, p.11-14, 2010.

FORNEL, P.; DELISLE, F.; DEVAUCHELLE, P.; ROSENBERG, D. Effects of radiotherapy on pituitary corticotroph macrotumors in dogs: a retrospective study of 12 cases. Can. Vet. J., v.48, p.481-486, 2007.

GONÇALVES, A.S.P. Avaliação dos desvios no posicionamento da IMRT prostática com marcadores fiduciais versus estruturas anatômicas. 2013. 74f. (Mestrado em Radioterapia) - Escola Superior de Tecnologia da Saúde de Lisboa, Instituto Politécnico de Lisboa, POR.

GREEN, E. M.; FORREST, L.J. ADAMS, W.M. A vacuum-formable mattress for veterinary radiotherapy positioning: comparison with conventional methods. Vet. Radiol. Ultrasound, v.44, p.476-479, 2003.

HANSEN, K.S.; THÉON, A.P.; DOETEROCH, S.; KENT, M.S. Validation of indexed radiotherapy head positioning device for use in dogs and cats. Vet. Radiol. Ultrasound, v.56, p.448-455, 2015.

KENT, M.S.; BOMMARITO, D.; FELDMAN, E.; THEON, A. Survival, neurologic response, and prognostic factors in dogs with pituitary masses treated with radiation therapy and in treated dogs. J. Vet. Int. Med., v.21, p.10271033, 2007.

KIPPENES, H.; GAVIN, P.R.; SANDE, R.D. et al. Comparison of the accuracy of positioning devices for radiation therapy of canine and feline head tumors. Vet. Radiol. Ultrasound, v.41, p.371-376, 2000.

LAGE, M.F.A.A.; MERCICANO, A.D.; ZULIANI, G.C. Radioterapia. In: NOBREGA, A.I. et al. Tecnologia radiológica e diagnóstico por imagem. 4.ed. São Caetano do Sul: Difusão, 2012. p.247-264. 
LARUE, S.M.; CUSTIS, J.T. Advances in veterinary radiation therapy targeting tumors and improving patient comfort. Vet. Clin. Small Anim. v.44, p.909-923, 2014.

MACMANUS M.; D'COSTA, I.; EVERITT, S. et al. Comparison of $\mathrm{CT}$ and positron emission tomography/CT coregistered images in planning radical radiotherapy in patients with non-smallcell lung cancer. J. Med. Imag. Radiol. Oncol., v.51, p.386-393, 2007.

MARCINOWSKA, A.; WARLAND, J.; BREARLEY, M.; DOBSON, J. Comparison of two coarse fractionated radiation protocols for the management of canine pituitary macrotumor: an observational study of 24 dogs. Vet. Radiol. Ultrasound, v.56, p.554-562, 2015.

MARUO, T.; NAKAMURA, S.; FUKUYAMA, Y.; KAWARAI, S. Validation of new bite blocktype head-immobilization devices por radiotherapy in dogs. Vet. Radiol. Ultrasound, v.54, p.674-679, 2013.

MCENTEE, M.C. A survey of veterinary radiation facilities in the United States during 2001. Vet. Radiol. Ultrasound, v.45, p.476-479, 2004.

MICHELON, E.; COLENCI, B.; PAULA, V. Diferenças entre os exames de tomografia computadorizada realizados para fins diagnósticos e para planejamento radioterápico. Discipl. Sci. Sér. Ciênc. Nat. Tecnol., v.13, p.8191, 2012.
MOORE, S.A. Radiation therapy for the treatment of tumours in small companion animals. Vet. J., v.164, p.167-187, 2002.

MOORE, S.A.; O'BRIEN, D.P. Canine pituitary macrotumors. Compendium, v.30, p.33-41, 2008.

MORRIS, J.; DOBSON, J. Oncologia de pequenos animais. Curitiba: Roca, 2007. p.5556.

NELSON, R.W.; COUTO, G. Medicina interna de pequenos animais. 5.ed. Rio de Janeiro: Elsevier, 2015. 1512p

SCHWARZ, T.; SAUNDERS, J. Veterinary computed tomography. [New York]: John Wiley \& Sons, 2011. 575p.

THÉON, A.P.; FELDMAN, E.C. Megavoltage irradiation of pituitary macrotumours in dogs with neurologic signs. J. Am. Vet. Med. Assoc., v.213, p.225-231, 1998.

VETTORATO, M.C.; FERNANDES, M.A.R.; VULCANO, L.C.; FOGAÇA, J.L. Principais avanços e aplicações da radioterapia na medicina veterinária. Tekhne e Logos, v. 8, n. 1, p. 103$118,2017$.

WITHROW, S.J.; VAIL, D.M.; PAGE, R. Withrow and MacEwen's small animal clinical oncology. 5.ed. [Philadelphia]: Elsevier Saunders, 2013. 763p. 